\title{
Possibilities of Using Brownfields After Mining and Processing of Mineral Resources in Slovakia
}

\author{
Zuzana Šimková1, ${ }^{1,}$, Andrea Seňová ${ }^{1}$, Adriana Divoková $^{1}$, Michaela Očenášová ${ }^{1}$, and Peter \\ $\operatorname{Varga}^{1}$ \\ ${ }^{1}$ Institute of Earth Resources, Faculty of Mining, Ecology, Process Control and Geotechnologies, \\ Park Komenského 19, 04200 Košice, Slovakia
}

\begin{abstract}
The article deals with possibilities of brownfields using after mining and processing of mineral resources in the Slovak Republic, which represent not enough used or unused land, including administrative buildings or mechanical engineering objects. These types of brownfields are often accompanied by environmental burdens in various forms and levels of contamination of individual environmental components. Brownfields, whose degree of degradation and contamination is directly determined by the way of mining and processing of mineral resources, represent the so-called brown investments, which do not benefit the region where the brownfields are currently located. The article points to the current state of existence of environmental burdens as a result of mining and processing of mineral resources, which is also considered negative determinants of their occurrence. Based on the prioritization of negative and positive determinants of the possible use of brownfields after mining and processing of mineral resources, it concludes with a categorization of their possible further use.
\end{abstract}

\section{Introduction}

Brownfields after mining and processing of mineral resources were created as a result of radical changes in socio-economic structure, characterized by the shift of labor from primary (agriculture, forestry) to secondary (industry and construction) and currently to tertiary (trade, transport, services, public administration) of the sphere of civil life $[1,2]$. The environmental quality is not only influenced by the extraction of mineral resources, but also by the technological processes of processing and refining the extracted mineral resources. When opening, preparing and extracting a deposit, it is necessary to extract part of the accompanying rocks. These are temporarily or permanently stored in spaces created for this purpose (heaps). Similarly, by-products of treatment processes must be stored (sludge ponds). The way they are handled is of particular importance from an environmental point of view because they often cause a significant environmental burden [3].

\footnotetext{
* Corresponding author: zuzana.simkova@tuke.sk
} 
Areas of processing companies of raw materials were in past time situated also in vulnerable natural conditions without regard to the risks, affecting living environment, as well as health of the inhabitants, which is and will be dependent on sources of drinkable water from these areas. Technological processing of raw materials, but also activities, connected with their mining, there can contaminate water, soil and underground rocks. Many of elements that were applied in area of raw materials using in past time had been not considered as harmful, but scientific researches in last years proved their as toxic, carcinogenic, mutagenic or teratogenic effects. Using of such harmful and threatening elements is presently forbidden. They remain and pollute individual parts of living environment, presenting threatening of inhabitants' health and quality of living environment, because they entered to the environment due to the anthropogenic activities of the society [4]

\section{General characteristics of brownfields after mining and processing of mineral resources}

Brownfields after mining and processing of mineral resources are typical with the occurrence of heaps and sludge ponds, which from the environmental quality point of view, determine the formation of environmental burdens, which, in accordance with Act no. 569/2007 Coll. about geological works (geological law), "land pollution caused by human activity, which poses a serious risk to human health or the environment, groundwater and soil, with the exception of environmental damage".

Currently, 100 environmental burdens occur in the Slovak Republic due to mining and processing of mineral resources, while $44.0 \%$ of them are likely, $24.0 \%$ confirmed and $32.0 \%$ reclaimed. $59.0 \%$ of environmental burdens from the use of the raw material base are currently the burdens from the extraction of the raw material base and $41.1 \%$ from its processing, or storage, while most of them are environmental burdens from the mining of ore raw materials $(36.0 \%)$ and the least from the extraction of non-metallic raw materials $4.0 \%$ (Fig. 1) [5]. In addition to the occurrence of heaps and sludge ponds, the types of brownfields are also characterized by machine-technological equipment residues, which may contain fillings with chemical compounds which are risk for environmental quality and human health [4] In addition, the surrounding of brownfields is clearly identifiable in the landscape environment and in terms of environmental quality, also high-risk [6].

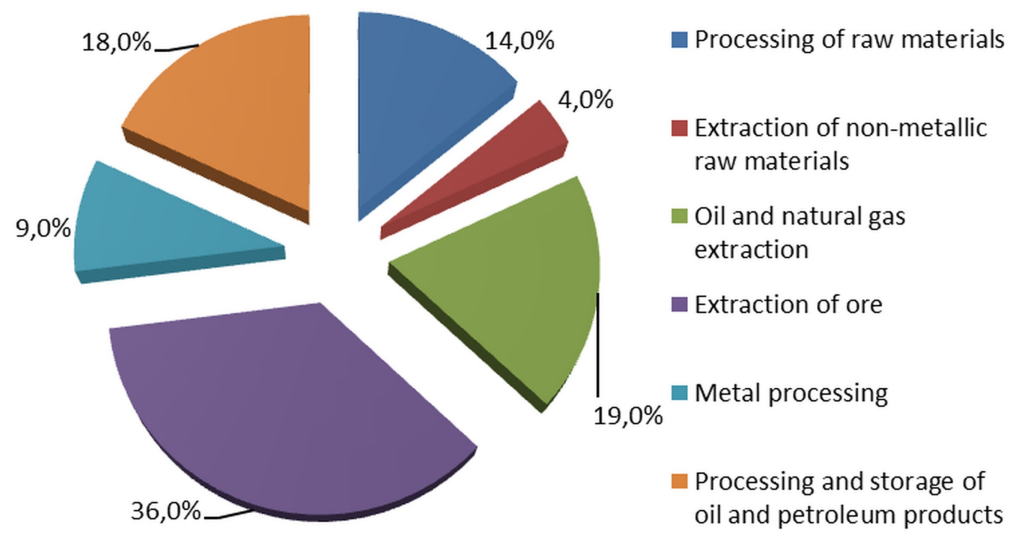

Fig. 1. Registered environmental burdens after mining and processing of raw materials in Slovakia. 
As it was mentioned above, it is possible to consider their occurrence on the territory of the Slovak Republic negative because their reuse would reduce the reduction of environmental quality, aesthetic character of the country, biodiversity, economic performance of the region in which they are localized. However, the possibilities of their use are directly determined by the need for investment capital to realize the reclamation of the described brownfields after mining and processing of mineral resources, as well as the expected benefits from investors' perspective.

\section{Methodology of determinants quantification for use of brownfields after mining and processing of raw materials}

For the purpose of defining the prioritization of determinants for use of brownfield after mining and processing of raw materials a tabulated overview was created in two areas positive and negative determinants. All the determinants were added a numerical value of the weight by accepting the generally valid condition of $\sum \alpha_{i}=1$. The values of the weights were quantified in terms of the Saaty matrix principles with dimensions of $\mathrm{m} x \mathrm{n}$, where $\mathrm{m}=1 \ldots \mathrm{i}$ and $\mathrm{n}=1 \ldots \mathrm{j}$, were given by the number of rows and columns, keeping the condition $\mathrm{m}=\mathrm{n}$. This symmetrical matrix also corresponds to the fact that the method is based on the interactive comparison of all predefined determinants of the same rank with the evaluation in Table $1[1,7]$.

Table 1. Assessment of negative and positive determinants in Saaty matrix.

\begin{tabular}{|c|c|}
\hline $\begin{array}{c}\text { Determinant } \\
\text { Value }\end{array}$ & Description of Comparative Determinants \\
\hline 1 & Determinants $\mathrm{i}$ and $\mathrm{j}$ are equivalent \\
\hline 3 & The determinant $\mathrm{i}$ is slightly preferred over the determinant $\mathrm{j}$ \\
\hline 5 & The determinant $\mathrm{i}$ is strongly preferred over the determinant $\mathrm{j}$ \\
\hline 7 & The determinant $\mathrm{i}$ is very strongly preferred over the determinant $\mathrm{j}$ \\
\hline 9 & The determinant $\mathrm{i}$ is absolutely preferred over the determinant $\mathrm{j}$ \\
\hline
\end{tabular}

Consequently, the values of 1 were assumed on the diagonal of the matrix, as we accepted the principle of comparison of the same determinant, i.e. their equivalence, and identified pairwise comparisons of the individual factors. If the determinant in the row is preferred over the determinant in the column, the reciprocal value was attributed. After this evaluation of individual determinant, partial line items were created according to $[1,7]$ :

$$
\mathrm{S}_{\mathrm{i}}=\prod_{j=1}^{f} S_{i j} \quad \mathrm{j}=1,2,3 \ldots \ldots \mathrm{f}
$$

where

$$
\begin{aligned}
& f \text { - number of factors, } \\
& S_{i j} \text { - particular factors. }
\end{aligned}
$$

Furthermore, the $R_{i}$ values for each criterion were quantified, i.e. row of matrix created according to the formula:

$$
\mathrm{R}_{\mathrm{i}}=\left(S_{i}\right)^{\frac{1}{f}}
$$

Based on these calculations, the sum of Ri was calculated based on it the final value of individual weights reflecting the interactions of the different determinants and their prioritization in the process of use of brownfields after mining and processing of raw materials was calculated. 


\section{Possibilities of using brownfields after mining and processing of mineral resources in Slovakia}

In terms of the issue and the above mentioned facts about the existence of brownfields after mining and processing of mineral resources, it was possible to define their negative and positive determinants for the needs of identifying their possible use in the Slovak Republic. The negative factors of the existence of brownfields after mining and processing of mineral resources were therefore included: occurrence of heaps (D1) and sludge ponds (D2), reduction of the aesthetic character of the landscape environment (D3), occurrence of environmental burdens (D4), devastated building objects (D5), soil (D6), reduced biodiversity (D7), and we quantified values of their weights $\alpha$ i for the need to define their prioritization in the process of identifying their potential use (Table 2).

Table 2. Quantification of negative determinants of brownfields after mining and processing of RM.

\begin{tabular}{|c|c|c|c|c|c|c|c|c|c|c|}
\hline Determinant & D1 & D2 & D3 & D4 & D5 & D6 & D7 & $\mathbf{S}_{\mathbf{i}}$ & $\mathbf{R}_{\mathbf{i}}$ & $\boldsymbol{\alpha}_{\mathbf{i}}$ \\
\hline D1 & 1 & 1 & 3 & $1 / 3$ & 5 & $1 / 3$ & 5 & 8.3333 & 1.354 & 0.17 \\
\hline D2 & 1 & 1 & 3 & $1 / 3$ & 7 & 7 & 5 & 245.0000 & 1.843 & 0.23 \\
\hline D3 & $1 / 3$ & $1 / 3$ & 1 & $1 / 5$ & 3 & 5 & $1 / 3$ & 0.1111 & 0.783 & 0.10 \\
\hline D4 & 3 & 3 & 5 & 1 & 7 & 5 & $1 / 3$ & 525.0000 & 2.006 & 0.25 \\
\hline D5 & $1 / 5$ & $1 / 7$ & $1 / 3$ & $1 / 7$ & 1 & $1 / 3$ & $1 / 5$ & 0.0001 & 0.356 & 0.04 \\
\hline D6 & 3 & $1 / 7$ & $1 / 5$ & $1 / 5$ & 3 & 1 & $1 / 3$ & 0.0171 & 0.636 & 0.08 \\
\hline D7 & $1 / 5$ & $1 / 5$ & $1 / 3$ & 3 & 5 & 3 & 1 & 0.6000 & 0.945 & 0.12 \\
\hline SUM & \multicolumn{10}{|c|}{} \\
\hline
\end{tabular}

Among the positive determinants of the use of brownfields we included: increasing employment (D1), increasing environmental quality (D2), supporting of social development (D3), supporting the business environment (D4), promoting economic development (D5), increasing nominal wage (D6) in the locality where reuse of brownfields, increase of tax revenues of municipalities (D7), and in the same way we quantify the values of their weights $\alpha \mathrm{i}$ for the need to define their prioritization in the process of identifying their potential use (Table 3 ).

Table 3. Quantification of positive determinants of brownfields after mining and processing of RM.

\begin{tabular}{|c|c|c|c|c|c|c|c|c|c|c|}
\hline Determinant & D1 & D2 & D3 & D4 & D5 & D6 & D7 & $\mathbf{S}_{\mathbf{i}}$ & $\mathbf{R}_{\mathbf{i}}$ & $\boldsymbol{\alpha}_{\mathbf{i}}$ \\
\hline D1 & 1 & $1 / 3$ & 3 & $1 / 3$ & $1 / 3$ & $1 / 3$ & $1 / 5$ & 0.0074 & 0.496 & 0.07 \\
\hline D2 & 3 & 1 & 3 & 3 & 1 & $1 / 3$ & $1 / 3$ & 3.0000 & 1.105 & 0.15 \\
\hline D3 & $1 / 3$ & $1 / 3$ & 1 & $1 / 3$ & $1 / 5$ & $1 / 3$ & $1 / 3$ & 0.0008 & 0.524 & 0.07 \\
\hline D4 & 3 & $1 / 3$ & 3 & 1 & 5 & $1 / 5$ & $1 / 3$ & 1.0000 & 1.000 & 0.14 \\
\hline D5 & 3 & 1 & 5 & $1 / 5$ & 1 & $1 / 3$ & 3 & 3.0000 & 1.105 & 0.15 \\
\hline D6 & 3 & 3 & 3 & 5 & 3 & 1 & $1 / 5$ & 81.0000 & 1.491 & 0.20 \\
\hline D7 & 5 & 3 & 3 & 3 & $1 / 3$ & 5 & 1 & 225.0000 & 1.636 & 0.22 \\
\hline \multicolumn{7}{|c|}{} & \multicolumn{10}{|c}{ SUM } & & & 7.358 & 1.00 \\
\hline
\end{tabular}



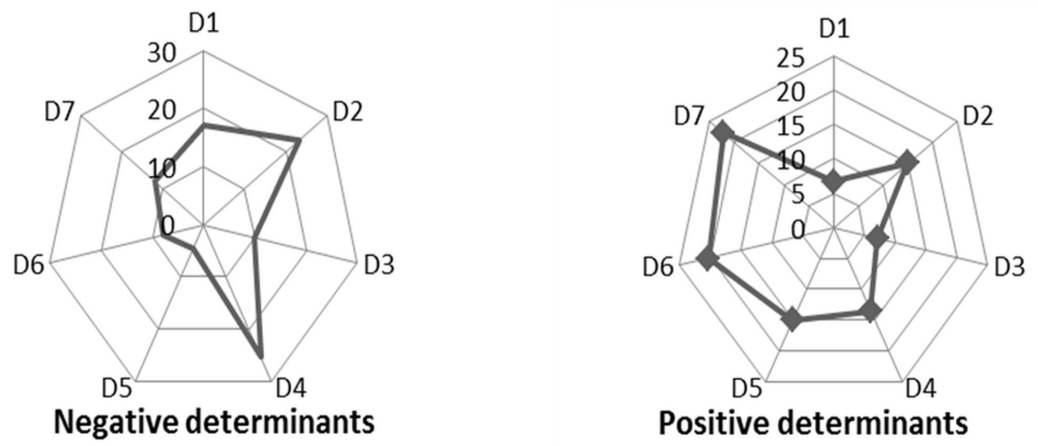

Fig. 2. Prioritization of negative and positive determinants use of brownfields after mining and processing RM.

On the basis of quantified prioritization of positive and negative determinants of brownfield utilization after mining and processing of raw materials, we then compiled a summary matrix of evaluation the possibilities of using these types of brownfields (Table 4), where it can be seen that the negative determinants $(51.85 \%)$ were slightly superior to the positive ones $(48.15 \%)$, with a scoring index value of 0.93 . Accordingly, we have also identified the category of brownfield utilization after mining and processing of raw materials, which can be considered as II. category (Table 5), it means high usefulness, which also indicates expected benefits for the investor to eliminate such a brown investment [8].

Table 4. Summary matrix of possibilities of using brownfields after mining and processing of RM.

\begin{tabular}{|c|c|c|c|c|}
\hline Determinant (+/-) & D & Partial score & Score & Scoring index \\
\hline occurrence of heaps & - & 8.86 & \multirow{7}{*}{51.85} & \multirow{14}{*}{0.93} \\
\hline occurrence of sludge ponds & - & 12.06 & & \\
\hline $\begin{array}{l}\text { reduction of the aesthetic character } \\
\text { of the landscape }\end{array}$ & - & 5.13 & & \\
\hline $\begin{array}{l}\text { occurrence of environmental } \\
\text { burdens }\end{array}$ & - & 13.13 & & \\
\hline devastated building objects & - & 2.33 & & \\
\hline soil & - & 4.17 & & \\
\hline reduced biodiversity & - & 6.18 & & \\
\hline increasing employment & + & 3.25 & \multirow{7}{*}{48.15} & \\
\hline increasing environmental quality & + & 7.23 & & \\
\hline supporting of social development & + & 3.43 & & \\
\hline promoting economic development & + & 6.54 & & \\
\hline increasing nominal wage & + & 7.23 & & \\
\hline wage & + & 9.76 & & \\
\hline $\begin{array}{c}\text { increase of tax revenues of } \\
\text { municipalities }\end{array}$ & + & 10.71 & & \\
\hline
\end{tabular}


Table 5. The categorization of usefulness brownfields after mining and processing of RM.

\begin{tabular}{|c|c|c|}
\hline \multicolumn{2}{|c|}{ Category of usefulness of brownfields } & Scoring \\
\hline I. category & Very high usefulness & More than 1.2 \\
\hline II. category & High usefulness & $1.19-0.9$ \\
\hline III. category & Average usefulness & $0.89-0.7$ \\
\hline IV. category & Low usefulness & $0.69-0.5$ \\
\hline V. category & Very low usefulness & $0.49-0.3$ \\
\hline VI. category & Ineffective usefulness & 0.29 and less \\
\hline
\end{tabular}

\section{Conclusion}

The development of the solution to the issue of brownfield using after mining and processing of raw materials is directly determined by the degree of total devastation of the area due to the mining and processing of mineral resources in interaction with the occurrence of environmental burdens. These facts determine the economic risks in the form of additional, respectively unexpected costs that significantly reduce possibilities for reuse of the described brownfield types in terms of investor expectations.

For these reasons, the article pointed out the necessity predicting of categorization the use of brownfields after mining and processing of raw materials based on a scoring index of clearly defined positive and negative determinants, including their systemic prioritization process, as a tool for decision making about possibilities of their reuse.

Contribution is partial result of projects solving VEGA MŠVVaŠ SR 1/0515/18 „The decisionmaking model of process of evaluating raw material policy of regions".

\section{References}

1. H. Pavolová, T. Bakalár, E. M. A. Emhemed, Z. Hajduová, M. Pafčo, Entrepreneurship Sustainability Issues, 6, 3 (2019)

2. S. Khouri, H. Pavolová, M. Cehlár, T. Bakalár, Metalurgija, 55, 3 (2016)

3. M. Cehlár, L. Domaracká, I. Šimko, M. Puzder, Production Management and Engineering Sciences (CRC Press/Balkema, Leiden, 2016)

4. H. Pavolová, A. Csikósová, T. Bakalár, Appl. Mech. Mater., 209, 211 (2012)

5. S. Khouri, H. Pavolová, K. Čulková, Z. Šimková, Raw material base using and sustainable development in Slovakia (Ecoletra, Lewes, 2018)

6. H. Pavolová, A. Csikósová, K. Čulkova, M. Antošová, Maria, Appl. Mech. Mater., 152, 154 (2012)

7. B. Hlavňová, H. Pavolová, Knowledge for Market Use 2017: People in Economics Decisions, Behavior and Normative Models (Palacký University, Olomouc, 2017)

8. M. Cehlár, M. Antošová, A. Seňová, SGEM 2013, 2 (STEF92 Technology Ltd., Albena, 2013) 